\title{
Child Trafficking vs. Child Sexual Exploitation: Critical reflection on the UK media reports
}

\author{
Elena Krsmanovic
}

\section{Abstract}

This article explores how UK media narratives construct sexual exploitation of British children as a phenomenon to be approached differently than sexual exploitation of trafficked minors who are non-British nationals. Qualitative analysis of media articles that frame infamous child sexual exploitation cases as occurrences of human trafficking shows that they bank on the motifs from the historical white slavery myth. Thereby, these articles endorse the stereotypes of white victim and foreign trafficker and obscure the diversity of trafficking victims, perpetrators, and experiences. Furthermore, comparison between media reports focusing on cases involving British minors, on the one hand, and minors from abroad, on the other hand, reveals that only the former problematise inadequate victim assistance and systemic failures in dealing with sexual exploitation of minors. This leaves structural causes of child trafficking unaddressed, promotes differential treatment of victims based on their nationality, and stigmatises whole communities as immoral and crime-prone.

Keywords: child trafficking, child sexual exploitation, UK, differential treatment of minor victims based on their nationality

Please cite this article as: E Krsmanovic, 'Child Trafficking vs. Child Sexual Exploitation: Critical reflection on the UK media reports, Anti-Trafficking Review, issue 16, 2021, pp. 69-85, https://doi.org/10.14197/atr.201221165

\section{Introduction}

In the first half of 2020, the year this article was first drafted, illusions of equality, universal rights, and social justice were powerfully challenged both by the disproportionate impact of COVID-19 on already disadvantaged populations, and by the Black Lives Matter protests that followed the murder of Mr George

This is an open-access article distributed under the terms of the Creative Commons Attribution License (CC-BY). Under the CC-BY license, the public is free to share, adapt, and make commercial use of the work. Users must always give proper attribution to the authors and the Anti-Trafficking Review. 
Floyd in the United States of America. Riding the wave of this disillusioning momentum, this article tracks discursive strategies employed by the UK media that construct trafficking of British minors for sexual exploitation as different to trafficking of foreign minors exploited in the UK sex industry. This distinction between victims, and the subsequent unequal access to victim assistance and protection, are neither UK-specific nor new phenomena. Evidence of survivors of human trafficking being discriminated against and categorised based on their country of origin, skin colour, gender, experiences, appearance, and behavioural patterns is global in scope and abundant in quantity. ${ }^{1}$ News media play into this rhetoric and further endorse the idea that certain victims are 'legitimate', while others are not and thereby less worthy of sympathy and care. ${ }^{2}$ The reporting on the phenomenon of child sexual exploitation, on the other hand, has generally received less scholarly attention. ${ }^{3}$ Particularly, the question of how the problematic framing of notable child sexual exploitation (CSE) cases, labelled as 'child trafficking' in the UK press, compares to the reporting on the exploitation of non-British children, remains underexplored. For that reason, this article focuses on the differences between the two and their potential to stigmatise immigrant communities and contribute to the differential and unequal treatment

1 See for instance R Annison, In the Dock: Examining the UK's criminal justice response to trafficking, Anti-Trafficking Monitoring Group, London, June 2013, https://ecommons. cornell.edu/handle/1813/102138; RHJM Staring, 'Human Trafficking in the Netherlands: Trends and recent developments', International Review of Law, Computers \& Technology, vol. 26, no. 1, 2012, pp. 59-72, https://doi.org/10.1080/13600869.201 2.646797; H Pandya and H Pandya, 'Racial Discrimination and Human Trafficking in India: Challenges ahead', International Journal of Humanities and Social Science, vol. 1, no. 6, 2011, pp. 97-121, http://www.ijhssnet.com/journals/Vol._1_No._6; June_2011/12.pdf; D Brennan, 'Competing Claims of Victimhood? Foreign and domestic victims of trafficking in the United States', Sexuality Research \& Social Policy, vol. 5, no. 4, 2008, pp. 45-61, https://doi.org/10.1525/srsp.2008.5.4.45; J Doezema, 'Loose Women or Lost Women? The re-emergence of the myth of white slavery in contemporary discourses of trafficking in women', Gender Issues, vol. 18, no. 1, 1999, pp. 23-50, https://doi.org/10.1007/s12147-999-0021-9.

2 E Krsmanovic, Media Framing of Human Trafficking for Sexual Exploitation. A study of British, Dutch and Serbian media, Eleven International Publishing, The Hague, 2020; the complete issue 7 of the Anti-Trafficking Review; M Pajnik, 'Media framing of trafficking', International Feminist Journal of Politics, vol. 12, issue 1, 2010, pp. 45-64, https://doi. org/10.1080/14616740903429114; and many others.

3 Among notable exceptions, see e.g. E Cockbain and W Tufail, 'Failing Victims, Fuelling Hate: Challenging the harms of the "Muslim grooming gangs" narrative', Race \& Class, vol. 61, issue 3, 2020, pp. 3-32, https://doi.org/10.1177/0306396819895727; J Britton, 'Challenging the Racialization of Child Sexual Exploitation: Muslim men, racism and belonging in Rotherham', Ethnic and Racial Studies, vol. 42, issue 5, 2019, pp. 688-706, https://doi.org/10.1080/01419870.2018.1467030; W Tufail, 'Rotherham, Rochdale, and the Racialised Threat of the "Muslim Grooming Gang", Crime, Justice and Democracy, vol. 4, issue 3, 2015, pp. 30-43, https://doi.org/10.5204/ijcjsd.v4i3.249. 
of children who experience sexual abuse and exploitation in the UK, based on their nationality.

This contribution presents an analysis of articles that treat CSE as a form of child trafficking. The analysed texts were published in British online media in the period of 2011-2015, when major sexual exploitation cases in Rotherham, Rochdale, Derby, Oxford, Telford, and Peterborough were heavily reported by the local and national media. These cases involved grooming and exploitation of hundreds of minors by groups of men over a period of over three decades and were followed by increased political and public attention to CSE. ${ }^{4}$ Charged conversations focusing on the ethnic background of the perpetrators became central to the CSE debate. Next to the worries linked to men grooming minors and exploiting them sexually, the British public was alarmed over the failed institutional response to exploitation of such magnitude. Lack of awareness among social workers and other professionals working with minors that were considered particularly vulnerable to this form of abuse was recognised as an underlying problem. Britons became outraged about victimised minors being failed by the system. Despite being involved with social services prior to or during their exploitation, these minors were not recognised as victims for a long time. ${ }^{5}$ With this increased media attention, the issue of CSE became almost synonymous with grooming and exploitation of minors by groups of adult men, ${ }^{6}$ described as Muslim, Pakistani, or Asian. ${ }^{7}$

In order to analyse media reporting on CSE cases, however, it is important to first untangle the distinct, but partly overlapping, terms of CSE and human trafficking. Both human trafficking and CSE are legally defined in the UK

4 See A Jay, Independent Inquiry into Child Sexual Exploitation in Rotherham 1997-2013, Rotherham Metropolitan Borough Council, 2014, https://www.rotherham.gov.uk/ downloads/file/279/independent-inquiry-into-child-sexual-exploitation-inrotherham, and other investigative reports by the Independent Inquiry into Child Sexual Abuse (IICSA) available at https://www.iicsa.org.uk.

5 S Hallett, "An Uncomfortable Comfortableness": "Care", child protection and child sexual exploitation', British Journal of Social Work, vol. 46, issue 7, 2016, pp. 2137-2152, https://doi.org/10.1093/bjsw/bcv136.

6 M Melrose, 'Twenty-First Century Party People: Young people and sexual exploitation in the new millennium', Child Abuse Review, vol. 22, issue 3, 2012, pp. 155-168, https:// doi.org/10.1002/car.2238.

7 In the media discourse of CSE cases in the UK, 'Asian' refers to South Asian communities, particularly the Pakistani community in the UK. Therefore, I use the term in this article, too, but italicised, in order to signal that it pertains to this specific group of Asian diaspora. For the same reason, italicised formatting is applied to the terms Muslim and Pakistani that refer to perpetrators involved in the reported CSE cases. For more details, see Tufail. 
criminal law. Child sexual exploitation entails paying for the sexual services of a child (a person aged under 18), causing or inciting sexual exploitation of a child, controlling a child in relation to sexual exploitation, and arranging or facilitating such exploitation. UK legislators determined that a child is sexually exploited if on at least one occasion and whether or not compelled to do so, s/he offers or provides sexual services to another person in return for payment or a promise of payment to the child or a third person, or if an indecent image of the child is recorded. ${ }^{8}$ On the other hand, British legislation stipulates that human trafficking is committed if a person arranges or facilitates the travel of another person with a view to exploit that person. ${ }^{9}$ In this sense, CSE is narrower than human trafficking, which can affect both children and adults and involve types of exploitation other than sexual. Another difference is the travel aspect that is central in the legal definition of human trafficking in UK law, while it may but does not need to be part of the crime act of CSE. ${ }^{10}$

Since this article is focused on the discourse of the press and not the law, the legal distinction drawn in the paragraph above is brief and simplified. However, it is important to note that British media rarely acknowledge the difference between the two phenomena, and generally equate 'child sexual exploitation' with trafficking of young British nationals by organised crime groups of Asian men. ${ }^{11}$ Moreover, the media provide multiple definitions of CSE, such as domestic trafficking of children for money, organised child trafficking, a form of child sexual abuse, street grooming, a sexual act with a minor for which they or someone else receives payment, etc. Building on the existing literature critical of the CSE discourses, ${ }^{12}$ this article pays particular attention to media framing of CSE cases that results in promoting differential treatment of minors who fall victim to sexual exploitation based on their nationality.

8 Serious Crime Act, 2015, https://www.legislation.gov.uk/ukpga/2015/9/contents/ enacted.

9 Modern Slavery Act, 2015, http://www.legislation.gov.uk/ukpga/2015/30/contents/ enacted.

10 It is precisely this emphasis on movement that the British legislation attributes to the crime act of human trafficking that was criticised by anti-trafficking experts concerned with protecting human rights. For instance, Beddoe and Brotherton critiqued the British Modern Slavery Act of 2015 over potential obstacles in prosecuting cases where the movement of victim(s) is difficult to prove. See C Beddoe and V Brotherton, Class Acts? Examining modern slavery legislation across the UK, Anti-Trafficking Monitoring Group, London, 2016, https://www.antislaverycommissioner.co.uk/media/1253/ class-acts.pdf.

11 Krsmanovic.

12 Tufail; Cockbain and Tufail. 


\section{Methods}

In my $\mathrm{PhD}$ research, I analysed the framing of human trafficking for sexual exploitation in British, Serbian, and Dutch online media. ${ }^{13}$ The research was based on a combined quantitative and qualitative content analysis of media reports ${ }^{14}$ and interviews with journalists and anti-trafficking experts who provide information about human trafficking to the media. ${ }^{15}$ This research demonstrated that mediated accounts of human trafficking are deeply rooted in societal fears about security, hegemonic ideas about gender, hierarchy of labour mobility, erotic obsessions, and morality; furthermore, reports in all three countries were characterised by a concerning propensity towards reiteration of gender stereotypes and racial and ethnic biases towards victims and perpetrators of human trafficking. ${ }^{16}$

This article, however, is focused on a specific sub-sample of 151 media articles that framed human trafficking for sexual exploitation as CSE. This sub-sample was identified as somewhat of an anomaly in my doctoral research. Namely, while journalists in all three countries predominantly framed human trafficking as a criminal justice and prostitution-related issue, every tenth article in the UK press focused on one of the big CSE cases described in the introduction and framed them as trafficking of British youth by ethnic gangs who exploited them sexually. The decision to treat CSE as a separate frame in my original research was motivated by the large number of articles that focused on it (151 out of 1,544) and their unique features that stood out from the rest of the sample. Here, it is important to note that the narratives in the British press differed between victims who were British minors and those who were not. Another distinctive feature of the articles on British minors was calls for the establishment of a more comprehensive victim support mechanism, which was seldom a topic

13 Online media stand here for journalistic outlets of both tabloid and broadsheet orientation.

14 The sample for quantitative analysis consisted of 1,544 articles published in British journalistic online media, 776 in Dutch journalistic online media, and 280 in Serbian online media in the period between 2011 and 2015. The qualitative analysis in that research was conducted on a smaller sample consisting of 30 per cent of articles in the original sample. The sub-sample for the qualitative analysis was constructed with the use of stratified sampling.

15 Forty-eight interviews were completed in this research: thirty with experts in antitrafficking (including a national anti-trafficking coordinator, representatives of NGOs, police, academics, legal experts, etc.) and eighteen with media professionals specialising in the topic of human trafficking (journalists, editors, and documentary film-makers).

16 Krsmanovic. 
in articles that dealt with foreign or adult victims. ${ }^{17}$

The analysed articles were published in the journalistic online media ${ }^{18}$ in the UK between 2011 and 2015, the period when major CSE cases attracted a lot of attention due to the investigation and legal proceedings against the perpetrators. All articles were imported into the qualitative data analysis software NVivo. The analysis and coding process drew on Entman's conceptualisation of frames and their functions, which proposes that frames make some aspects of the news story more salient than others in order to promote certain problem definitions, causal interpretations, moral evaluations, and solutions for the problem described in the communicating text. ${ }^{19}$ Therefore, to analyse the data, I used a combination of predetermined coding categories: problem definitions, responsibility assigned for causing the problem(s), responsibility assigned for solving the problem(s), underlying moral judgements, and solutions offered, and emergent codes within these categories to analyse the data. I also coded images that were used to illustrate the articles using the emergent coding technique. ${ }^{20}$

While this article is primarily based on the analysis of these 151 media reports using the CSE frame, which predominantly are on British nationals, in the second part of this article, I contrast these with news reports dealing with trafficking of foreign minors exploited in the UK that were scrutinised in my PhD research. In my doctoral study, at least 400 articles from the UK sample dealt with cases that involved non-British minor victims exploited in the UK sex industry. ${ }^{21} \mathrm{Next}$ to the analysis of journalistic writings that encompasses both textual and visual

17 It is important to stress that the articles analysed in this contribution consider CSE to be a form of trafficking, even when it is not clear to what extent the travel element was present in the case. This is not to say that all journalistic publications in the UK confuse CSE and human trafficking. Rather, it is the search terms used to collect the data in my initial research that dictated the overlaps between trafficking and CSE narratives.

18 The journalistic outlets in the sample included tabloid media, such as the Daily Mail and Daily Mirror, which were the most represented. However, compact and broadsheet outlets such as The Guardian and The Daily Telegraph, were also well represented. The sample also included web presentations of the traditional electronic media (radio and television, e.g. the $B B C$ ). Finally, online platforms of daily locals had a high share in the analysed sample, accounting for approximately one-third of the sample.

19 R M Entman, 'Framing: Toward clarification of a fractured paradigm', Journal of Communication, vol. 43, issue 4,1993,pp. 51-58, https://doi.org/10.1111/j.1460-2466.1993. tb01304.x.

20 In emergent coding, codes used to categorise data emerge from the data itself.

21 This is a conservative estimate, since I only counted articles that explicitly mention the victim's nationality and age. The exact number is impossible to deduce because some articles would omit some of the information or use vague terms like 'youth' or 'very young' to refer to the victims. 
data, this article banks on records from eleven semi-structured interviews with anti-trafficking professionals (seven) and media experts (four) who specialise in the topic of human trafficking in the UK. Speaking to anti-trafficking actors who provide information to the media allowed me to better understand why a certain way of framing trafficking was preferred and what the consequences of such reporting on the perception and suppression of human trafficking are. Most interviews were conducted in person and several over Skype or phone. I recorded the interviews, transcribed and anonymised them, and imported the transcripts into NVivo. While coding the interviews, I was looking for topics relevant to dominant frames identified in the media analysis of trafficking reports. The interview data was used to validate and contextualise the findings of the media content analysis.

\section{Old Myth, Same Protagonists}

Media narratives on human trafficking still rest upon the white slavery myth, i.e., the idea that foreign men abduct and deceive young, white, Western girls into prostitution. This myth dates back to nineteenth-century narratives that emerged in response to European and American women migrating in search for labour. The re-emergence of this myth was already recognised by scholars in the late 1990s. Doezema compared the historical white slavery myth discourse to that of trafficking in women, and recorded prominence of overlapping motifs and characters: deceived innocence and youth were linked to victims, and moral corruption and foreignness to traffickers. She identified further similarities in fears and anxieties that underpin these discourses: in connection with the white slavery myth, concerns linked to the collapse of the traditional family, women's independence, and the national identity crisis; with regards to trafficking, the fear of immigration, multiculturalism, and jeopardised traditional values. ${ }^{22}$ This section of the article explores how the white slavery myth resonates with the narratives used to describe CSE cases in the UK press.

The race and ethnicity of the perpetrators, and often their religion, are the focal point of the majority of analysed texts. For instance, one opinion peace on the Rochdale case in 2012 framed the case as a racial issue caused by Asian men who prey on white British girls: 'All the men were of Asian background; all the victims were white. Yet we are asked to believe this: "Commenting on the case, Greater Manchester Police Assistant Chief Constable Steve Heywood denied that it was about race. He said: 'It is not a racial issue. This is about adults preying on vulnerable young children. It just happens that in this particular area and time the demographics were that these were Asian men."' Perhaps Mr Heywood would like

22 Doezema, p. 40. 
to explain why some spokesmen for the Asian community don't agree with him. ${ }^{23}$

In extreme cases, the guilt was extended from the perpetrators to the whole Asian community that was held accountable for not recognising or not reporting the abuse they were assumed to know of, based on 'the small size of their community'. Such was the case in an article published in the Daily Mail, where former Home Secretary Jack Straw asserted that the ethnic dimension of group grooming cases needed to be addressed, calling for harsher policing and addressing the denial within the Asian community, despite recognising in his statement that the majority of sex offenders in the UK are white. ${ }^{24}$ Public pleas to the Muslim community to acknowledge this problem and condemn it should be understood as a request "to "pledge of allegiance" to the state, nation and the hegemonic order'. ${ }^{25}$

Even when issues of race, ethnicity, and religion were not explicitly tackled in the articles, the press found subtler ways to highlight their importance. Here, it helps to look at the demographic data on perpetrators and victims that was shared in the articles. Only 5 per cent of texts that frame human trafficking as CSE recognise the possibility of traffickers being white. On the other hand, close to 90 per cent highlight explicitly that perpetrators are foreign men. Most frequently used labels are Asian, Pakistani, and Muslim. Comparing media outlets with different political orientations yields more interesting results. For instance, looking at how a specific case is covered in conservative vs. liberal media reveals the propensity of the former to conceal the fact that these Asian traffickers are most frequently British citizens. They employ various strategies to this end, for example, to disclose the nationality of the foreign members of the group. Media also rely on vague terms that are easily misinterpreted, such as 'Asian community', and 'foreign gang'. In order to portray offenders as essentially non-British, the articles would also omit information on their nationality and country of origin, but put forward phrases like 'Muslim men' or use their distinctly 'foreign-sounding' surnames (e.g. Ali, Azis, Hassan, Sultan, Khan, Ahmed, etc.) to signify their ethnic otherness. Emphasis on the neighbourhoods that the perpetrators originate from and that are known to be predominately populated by immigrants, were also used to communicate to the local readership that the perpetrators are 'foreign'. This stereotypical representation fits the white slavery

23 D Thompson, 'Manchester Sex Trafficking Case "Not About Race" Say police. Do they expect us to believe that?', The Telegraph, 8 May 2012.

24 M Robinson, 'Council and Police Had 127 Warnings About Sex Abuse in Town Where Asian Gang Raped Dozens of Children, Finds Damning Report', Daily Mail, 27 September 2012, http://www.dailymail.co.uk/news/article-2209261/Council-83warnings-sex-abuse-town-Asian-sex-gang-spent-years-raping-dozens-childrenyoung-10.html.

Tufail. 
myth and testifies of the continuing trend in reporting on human trafficking and related issues to situate foreign men as inherently evil, exploitative, and disrespectful of women. Furthermore, a recent report issued by the Home Office found that the majority of perpetrators involved in CSE cases are white men under the age of $30 .{ }^{26}$ Hence, the stigmatisation of Asian communities is not the only negative effect of this media bias; it can also result in obscuring the dangers of minors being sexually exploited by white individuals. This, in turn, can have a negative effect on the awareness of risks related to both human trafficking and CSE.

The portrayal of CSE victims in the analysed sample shows similarity to the "white slave' stereotype, too. Victimised minors are referred to as British children, white girls, and UK-born children. Yet, if the exploited minors were from a minority group, this information would frequently be omitted. Only six articles mention that ethnic minority British minors (four articles) and foreign children (two articles) are victimised, too. This affirmed the white slavery narrative in which all perpetrators are foreign and dark skinned, while victims are white, but stands in contrast to Doezema's conclusion that contemporary discourses on trafficking refer to sexual exploitation of foreign women from less developed countries, mainly Eastern Europe. ${ }^{27}$ While foreign victims used to be in the focus of the anti-trafficking discourse two decades ago when Doezema wrote her article, in recent years, the focus has shifted to domestic victims. ${ }^{28}$ Therefore, it is likely that equating CSE with human trafficking in the public discourse serves the same purpose of promoting the idea of increased vulnerability of domestic citizens to the foreign evils supposedly inherent in the phenomenon of human trafficking. This idea and its consequences will be explored later in this article.

Vivid depictions of the violence inflicted upon the exploited youths were often provided in the articles on CSE cases. These unnecessarily detailed and dehumanising accounts of victims' suffering were encountered in online tabloids, as well as outlets of more serious formats. An excerpt from an article published in The Independent exemplifies this: 'The girls were raped, gang-raped, put to work as prostitutes, rented out for sadistic torture sessions. The girls were

26 J Grierson, 'Most Child Sexual Abuse Gangs Made up of White Men, Home Office Report Says', The Guardian, 15 December 2020, https://www.theguardian.com/ politics $/ 2020 / \mathrm{dec} / 15 /$ child-sexual-abuse-gangs-white-men-home-office-report.

27 Doezema.

28 This is in line with earlier research suggesting that British media are likely to overrepresent minors and domestic citizens as victims of human trafficking. For example, I have found that minors were over-represented as victims of human trafficking in the UK media in the period between 2011 and 2015. In the same period, there was a clear indication of a bias towards domestic citizens as the 'preferred' victim type by the UK press. For more details, see Krsmanovic. 
harmed with knives, cleavers and baseball bats. They were given illegal amateur abortions. The children would lie, drugged and drunk, in squalid guesthouses and filthy flats as queues of local paedophiles and opportunistic punters queued up to have sex with them. ${ }^{29}$

According to interviews with media professionals, these spectacles of violence bear huge potential to attract a desensitised audience that enjoys reading about horrific crimes. At the same time, anti-trafficking professionals identified this as one of the major obstacles in their collaboration with the media. '[The] difficulty lies in trying to raise awareness that the abuse is taking place, but avoid having media focus on the physical and sexual manifestation of that abuse. ${ }^{30}$ Consequences of such sensationalistic narratives go far beyond generating clicks and shares of news articles. Apart from dehumanising victims, voyeuristic displays of abuse are used to establish the inherently evil character of the trafficker versus the good, morally virtuous and, thus, superior character of the spectator. For example, an article based on an upsetting testimony of a victim that was taken by a dark-skinned man to a hotel room uses images from security camera footage from that hotel to show how the victim was lured into the room where she was abused. This provides a very detailed account of the victim's ordeal—one that the reader experiences through both reading her heart-breaking testimony and seeing convincing photographic evidence from the crime scene. By following the victim and her abuser from the reception to the hotel room, the reader thus becomes a post-factum witness of the minor's abuse, and consequently more invested in the story. ${ }^{31}$

Racial representation of perpetrators and their victims is equally homogenous in the images accompanying the analysed articles, which reinforce the white slavery myth. The sample is dominated by mugshots of Asian men or images of them taken in front of the court. Through the symbolic meaning of mugshots and courts, these men are thus likely to be viewed as criminal and guilty before any conviction. Tracking down the early tradition of photographing prisoners, Carney wrote that photographs 'marked their bodies with a stigma that was more than just symbolic; for in the developing culture of photographic circulation, the spectacle

29 G Dent, 'How Could So Many Years of Horrendous Abuse Go Unnoticed? In this case, the guilt extends way beyond Oxford sex traffickers', The Independent, 16 May 2013, https://www.independent.co.uk/voices/comment/how-could-so-many-yearsof-horrendous-abuse-go-unnoticed-in-this-case-the-guilt-extends-waybeyond-8617339.html.

30 Interview, London, 11 August 2016.

31 E Retter, 'Shocking Hotel Footage Captures Moment Girl Aged 13 Is Lured Into Room To Be Raped by Paedophile', Daily Record, 9 November 2014, https://www. dailyrecord.co.uk/news/uk-world-news/shocking-hotel-footage-capturesmoment-4597368. 
of the "brand" was extended and intensified'. ${ }^{32}$ Given the significant role of media in shaping public perceptions, the stigmatising effect of such images and their wide circulation should not be neglected. Research on the impact of the CSE case in Rotherham on ordinary Muslim men showed that negative feelings among the general public towards the photographed perpetrators of CSE can extend to those who look like them. ${ }^{33}$ Simultaneously, the one-sided racial representation of CSE perpetrators masks the fact that trafficking and child sexual exploitation are committed by white perpetrators as well. ${ }^{34}$

When it comes to the portrayal of victims, all images show white individuals. When stock images are used, graphic editors usually select photographs of children that are much younger than those involved in the reported cases. In these photographs, youth and victimhood are emphasised through children's postures and props used in the photographs. Children are often shown crying, holding stuffed animals, or curled into a foetal position-evoking feelings of empathy and a desire to protect. Yet, the empathy remains reserved to an ethnically and racially homogeneous group of children who look white/British and young.

The issue of race also emerged in the interviews with anti-trafficking professionals who were critical towards the media. They testified of difficulties they faced while trying to challenge the race narrative in their media appearances. For instance, one NGO representative said media were failing to frame the Rotherham case as gender-based violence against children because they were focusing on the 'race issue': 'I mean, we were on TV and they were asking us: "Well isn't this all about the race?" And we were saying: "No, it's about violence against children." So you do have competing issues and you do have competing discourses on top of that. ${ }^{35}$ This quote exemplifies how framing of the media can cloud the fundamental issue, such as violence against children, and shift the focus to perpetrators' origin, race and, often times, religion. There are some attempts to challenge the narratives congruent with the white slavery myth. ${ }^{36}$ Yet, the premise that the ethnic and religious backgrounds of the perpetrators, along with their disrespectful attitudes towards British women, make them prone to sexually exploitative and abusive behaviour is still widely

32 P Carney, 'Crime, Punishment and the Forces of Photographic Spectacle', in K J Hayward and M Presdee (eds.), Framing Crime: Cultural criminology and the image, Routledge-Cavendish, Abingdon, 2010, p. 21.

33 Britton.

34 Grierson.

35 Interview with an anti-trafficking expert from the UK, London, 6 July 2016.

36 See, for example, K Nguyen, 'Asia Girls "Hidden Victims" of Sexual Exploitation in UK', Thomson Reuters, 10 September 2013, https://news.trust.org/item/20130910154928aysie. 
spread. Voices challenging this perspective were heard mostly in the serious and left-oriented media that would sometimes oppose linking perpetrators to Islam, 'particularly if those involved never actually displayed any form of religious motivation in the first place.$^{37}$ But they were overshadowed by the hegemonic, racialised discourse. The underlying problem visible in the analysed articles was the hesitance to engage with sensitive topics and address both racist stereotypes typical of British society and the cultural taboos present among its South Asian communities, such as the taboo of sex, which I will now further elaborate on. This hesitance to have an open dialogue about CSE cases is displayed by the media and their sources_- people responsible for tackling this problem in Britain.

\section{All Victims Are Equal, But Some Are More Equal Than Others}

The findings in the previous section are in line with earlier research that demonstrated how discourse used to refer to CSE cases serves to position British Muslims as a perceived racialised threat to British society. ${ }^{38}$ In his analysis of the Rochdale and Rotherham CSE cases, for instance, Tufail has found that the popular discourse is centred on the notions of inferior cultures and dangerous masculinities of Muslim men. According to him, this racist discourse emerged following the release of the Independent Inquiry into Child Sexual Exploitation in Rotherham 1997-2013, and banked on colonial discourses that limited the debate on CSE and led Muslim communities in Britain to experience isolation, alienation, racist attacks, and criminalisation. I further elaborate his argument by showing how the racist discourse on Muslim perpetrators was accompanied by different victim narratives in media reporting on CSE cases (pertaining exclusively to British victims) and child trafficking cases (pertaining to the exploitation of non-British minors). Understanding of these differences is crucial to uprooting differential treatment of victims and securing equal protection of all minors who experience sexual exploitation.

Following Entman's framing theory, I looked at the following categories to identify these differences: problems identified by the press, who is assigned the responsibility for causing these problems, who is assigned the responsibility for solving them, what solutions are suggested for the identified problems, and what are the underlying moral bases/judgements associated with the two groups of articles - those on CSE of British victims and those on non-British victims of trafficking. The most prominent difference was that media articles

37 H Kesvani, 'Sermons Preached in Mosques Will Do Nothing To Prevent Child Sex Abuse in South Asian Communities', Independent, 2 July 2013, http:/ /www.independent. co.uk/voices/comment/sermons-preached-in-mosques-will-do-nothing-to-preventchild-sex-abuse-in-south-asian-communities-8683505.html. 
focusing on CSE (and British victims) were discussing the position of victims and problematising systemic failures in recognising them and providing adequate assistance in their recovery. For instance, a report on the Rochdale case states: While some organisations were consistently supportive in their response, overall child welfare organisations missed opportunities to provide a comprehensive, co-ordinated and timely response and, in addition, the criminal justice system missed opportunities to bring the perpetrators to justice. ${ }^{39}$

CSE-framed reports stressed the need for measures that strengthen institutional responses to the sexual exploitation of British minors. These measures include educating responders (the police, social services, teachers, and healthcare professionals) and promoting a multi-sectoral approach to identification, suppression, and relevant rectification action. Some articles offered more concrete solutions such as giving a specific minister formal responsibility for the issue, appointing child guardians to minors who have faced CSE, improving record keeping, and developing an offender database. Importantly, a large number of articles advocated for improving victim support, raising awareness of the issue, and investigating failed institutional responses.

On the other hand, articles that had to do with the exploitation of non-British minors were more focused on traffickers, whose presence in Britain was presented as the main problem. This meant that the solution to child trafficking proposed in these articles was to prosecute traffickers and prevent them from entering Britain in the first place. Most of these articles revolved around feelings of insecurity and fear of the Other in British society rather than around the fate of victims. Very few to none dealt with questions of adequate victim assistance, investigations of institutional failures, recovery and reintegration of victims, or including more actors in the fight against trafficking. ${ }^{40}$ This is problematic because it creates obstacles to publicly legitimising and effectively securing rights to protection and support as well as access to justice for foreign trafficked minors and victimised minors of ethnic minorities in the UK. While articles on CSE problematise very different issues to articles on trafficking of foreign minors, they all rest on the premise of paying tribute to the (ethnic) British national community and its security, at the cost of the security and safety of ethnic minorities in the UK. ${ }^{41}$

39 No author, 'Rochdale Abuse: Social services "missed opportunities", BBC, 27 September 2012, https://www.bbc.com/news/uk-england-manchester-19739073.

40 Krsmanovic.

41 Trafficking scholars focused on other European regions made similar conclusions in their studies, too. See, for instance, B C Oude Breuil and T Marguery, 'Freedom, Security and Justice for Whom? The case study of Bulgarian street prostitution in France', in T van den Brink, M Luchtman and M Scholten (eds.), Sovereignty in the Shared Legal Order of the EU-Core Values of Regulation and Enforcement, Intersentia, Cambridge, 2015, pp. 197-216. 
The underlying moral base in the CSE-framed articles was twofold. Articles promoted the idea that it is imperative to punish crime on the one hand, and to help and protect vulnerable children on the other. What stood out in the analysis is the firm connection between the two. Helping British children and protecting their rights was inextricably linked to prosecuting criminal gangs of foreign men involved in their exploitation. This connection makes sense in terms of prevention, and perhaps securing some sense of justice for the affected individuals. Yet, as I have concluded elsewhere, it overlooks the fact that systemic and comprehensive support for victims of trafficking needs to exist irrespective of the response to the criminals. Many failures of the system in the UK to provide such support are overlooked, and institutional efforts are directed primarily at criminalisation.

Interviews with UK experts involved in assisting trafficking survivors exposed additional concerns related to differential treatments of victims based on their nationality. 'For British children, their young age and nationality was always stressed, but their race and ethnic background were frequently concealed if they were not white. For children who came from outside the UK, some media would omit mentioning the fact that victims were minors, whilst stressing that they were foreign or that they came into the UK illegally. ${ }^{32}$ Anti-trafficking professionals also emphasised that some media reports portrayed older children (victims who were 16 or 17 years of age) as being lascivious and misbehaved, and suggested they were responsible for finding themselves in exploitative situations. My own analysis of CSE-framed articles did not show victim blaming by the media, ${ }^{43}$ but it is worrisome that UK press outlets tend to do that when the victims are foreign.

Further negative implications concern the failure to uproot systemic biases in response to CSE and child trafficking. The interviewed anti-trafficking experts warned that biases towards victims and perpetrators found in the media circulate among anti-trafficking responders, too. They emphasised the interconnectedness: biased professionals provide information to the media and media reports influence practitioners' views. A UK police representative I interviewed reflected on media and police prejudice towards victims of CSE and child trafficking: 'I think that comes up [in the media]. And I think that is the perception within policing as well. You talk about child sexual exploitation, involving suspects from Pakistani Asian communities, you straight away think about your victims being probably white. Where, when you talk about human

42 Interview, London, 6 July 2016.

43 In some of the articles, it was clear that children who suffered CSE encountered victim blaming on the institutional level (e.g. by the police and social services); however, the reports were critical of such systemic discrimination and oversights. 
traffickers, you probably think of your victims being non-UK victims. ${ }^{34}$

Additionally, only articles connecting CSE cases to human trafficking problematise omissions in policing work. These included police refusing to take action, considering victims as 'child prostitutes', deeming that children 'seemed happy' with their abusers, holding victims accountable if they consumed alcohol, or concluding that a 14-year-old child 'consented' to sex even though they were below the legal age to do so. Such criticisms are largely absent in reports on cases involving exploitation of foreign minors, which rather tend to glorify the work of the police in curbing human trafficking. Both groups of reports fail to consider if biases associated with perpetrators affected the work of the police. This is important because failure to investigate suspects that do not fit the foreign trafficker stereotype recognised by the police is likely to have a negative impact on eradicating human trafficking and CSE from British society.

The concern with the sexual exploitation of domestic minors by foreign men is deeply rooted in societal fears of the ethnic other and amplified by the discourse that asserts British borders and national identity are in crisis. In Britain, these anxieties were enhanced by Brexit campaigns that further contributed to negative attitudes towards migrants. ${ }^{45}$ Therefore, it is not surprising that the stereotype of the foreign trafficker continues to be reiterated in mediated representations of CSE cases. However, by representing the trafficker (migrant) as the source of the problem, such articles are promoting restrictive migration measures in response to the crime of human trafficking, even though these have been proven ineffective in both curbing sexual exploitation and addressing the dependencies that leave migrants at heightened risk of it. ${ }^{46}$ It also leads to the further marginalisation of South Asian communities in the UK. Lastly, these biases can negatively affect public awareness, and thus people's

44 Interview, London, 29 July 2016.

45 A O’Neill, 'Hate Crime, England and Wales 2016/17. Statistical Bulletin 17/17', Home Office, London, 2017, https://www.gov.uk/government/uploads/system/uploads/ attachment_data/file/652136/hate-crime-1617-hosb1717.pdf; FLEX, Migration Advisory Committee Call for Evidence: EEA-workers in the UK labour market, Focus on Labour Exploitation, London, 27 October 2017, http://www.labourexploitation.org/ sites/default/files/publications/MAC_EEAworkersCommission_FLEXsubmission. pdf.

46 J Berman, '(Un)Popular Strangers and Crises (Un)Bounded: Discourses of sextrafficking, the European political community and the panicked state of the modern state', European Journal of International Relations, vol. 9, issue 1, 2003, pp. 37-86, https:/ / doi.org/10.1177/1354066103009001157; S Sassen, 'Women's Burden: Countergeographies of globalization and the feminization of survival', Journal of International Affairs, vol. 53, no. 2, 2002, pp. 503-524; K Kempadoo and J Doezema (eds.), Global Sex Workers: Rights, resistance, and redefinition, Routledge, New York, 1998. 
ability to understand human trafficking, assess related risks, and protect themselves from exploitative situations.

Finally, it should be noted that media treatment of CSE as trafficking can also have a negative impact on victims of CSE who have not been trafficked. The typically punitive, crime-control approach to trafficking means that the social and economic factors that make children vulnerable are ignored. In her empirical study of experiences of children who survived CSE, Hallet concluded: 'The current focus on grooming, and the emphasis on young people's lack of agency, deflects attention from much wider socioeconomic structures that cause adversity, whilst also directing practice to see the needs and wishes of an individual young person as secondary to their protection. ${ }^{37}$

\section{Conclusion}

The media plays a significant role in supporting the efforts to address human trafficking: it can increase awareness and contribute to prevention as well as to the development of policies and responses to it. ${ }^{48}$ Media can also play a role in monitoring institutions involved in tackling the issue, deconstructing or reinforcing stereotypes, and shaping the environment in which victims recover-be it to become more supportive or more stigmatising. ${ }^{49}$

As this article has shown, however, stereotypical media representation of CSE cases as trafficking reinforce the white slavery myth of foreign men coming to the UK to corrupt local (white) girls and force them into prostitution. These evil foreign traffickers are, according to the analysed articles, the source of the problem. Journalists did not explore whether men originating from certain countries are indeed more likely to exploit young women, and if so, for what reasons. Lack of such investigations leaves the reader with an oversimplified, stereotypical representation. This, in turn, creates grounds for further discrimination, racism, and other underlying factors that push minority communities into further vulnerability to victimisation and over-policing by law enforcement agencies. Biases can also have a negative effect on public awareness, and thus people's ability to understand human trafficking, assess related risks and protect themselves against exploitative situations.

47 Hallett.

48 Krsmanovic; S Rodríguez-López, '(De)constructing Stereotypes: Media representations, social perceptions, and legal responses to human trafficking', Journal of Human Trafficking, vol. 4, issue 1, 2018, pp. 61-72, https://doi.org/10.1080/23322705.2018. 1423447; G J Gulati, 'News Frames and Story Triggers in the Media Coverage of Human Trafficking', Human Rights Review, vol. 12, no. 3, 2010, pp. 363-379, https:// doi.org/10.1007/s12142-010-0184-5.

49 Krsmanovic. 
On the other hand, the comparison of articles focusing on CSE cases of British victims and those that deal with child trafficking for sexual exploitation of nonBritish youths yielded other alarming findings. While media reports focused on the abuse of British minors call for more comprehensive measures of social protection, articles on trafficking of foreign minors only promote harsher policing and prosecution of traffickers. This approach leaves large gaps in addressing the root causes of trafficking and other forms of sexual abuse against minors. Additionally, media reports not only promote differential treatment of victims based on their nationality, they also take an active part in this differential treatment (e.g. by concealing that foreign victims are minors and emphasising the youth of the exploited British minors). Only by addressing these problems can the journalistic media be used to effectively support the fight against child trafficking and sexual exploitation.

Elena Krsmanovic, PhD, is an Assistant Professor of Criminology at the Faculty of Law, Utrecht University, and a media criminologist. Krsmanovic conducted extensive research on media framing of human trafficking for sexual exploitation and visual representation of trafficking survivors. She is currently researching media securitisation and sex work representation, and will soon start a research project exploring mobile banditry in Europe. Prior to her career in academia, Krsmanovic worked as a TV and radio journalist in Serbia. Email: E.Krsmanovic@uu.nl 